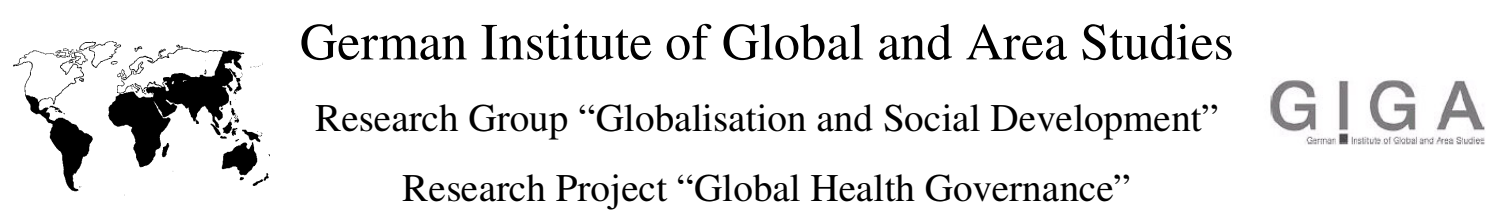

Research Project "Global Health Governance"

14.11 .2006

\title{
Between Conflict and Cooperation - \\ Global-National Interfaces and the Fight against HIV/AIDS in Brazil and South Africa
}

\author{
Paper prepared for the International Workshop \\ "Defining and Shaping the Architecture for Global Health Governance. Current Issues and \\ Future Perspectives" (February, 22-24 2006, Hamburg) \\ German Institute of Global and Area Studies (GIGA) \\ in Cooperation with WHO, supported by Volkswagen Foundation, BMGS and GTZ
}

Christian von Soest, Gilberto Calcagnotto and Martin Weinel ${ }^{1}$

\footnotetext{
${ }^{1}$ Christian von Soest and Gilberto Calcagnotto are affiliated to the GIGA German Institute of Global and Area Studies, Hamburg, Martin Weinel is based at the School of Social Sciences at Cardiff University. The authors wish to sincerely thank the other members of the GIGA Global Health Governance project group, whose input have been extremely helpful. The case study on South Africa, the basis for the South Africa part of this paper, gained from Gero Erdmann's (GIGA) input and support. Special thanks go to the respondents interviewed for this study. Their information and perceptions were an invaluable contribution for assessing the influence of Global Health Governance in the fight of HIV/AIDS in Brazil and South Africa.
} 


\section{CONTENTS}

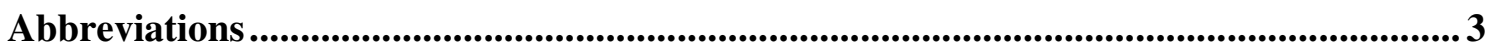

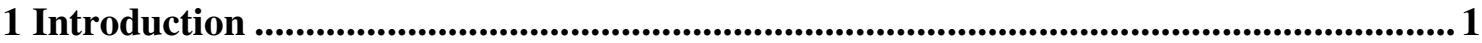

2 Resource-transfer Interfaces: Different Degrees of Autonomy from the Global Level . 3 3 Organisational Interfaces: Important Indicator for Conflict and Cooperation.............. 7

4 Legal Interfaces: Disputes with Repercussions for the Global Level........................... 10

5 Discursive Interfaces: Strong Interaction between National and Global Level............. 14

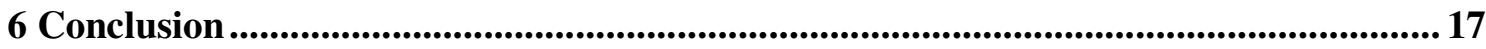

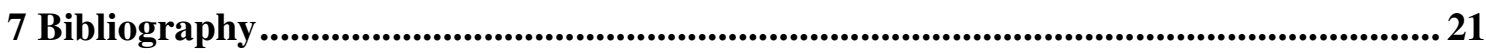

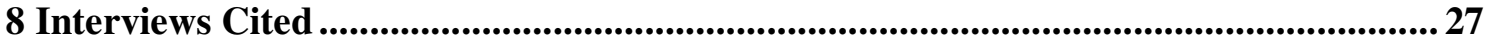




\section{Abbreviations}

ABIA

ACT-UP

AIDS

ANC

ARVs

ART

BSAP

CEN

CNAIDS

CPtech

ECI

EU

GAPA

GFATM / Global Fund

GHG

GIGA

GNI

Grupo Pela VIDDA

GTZ

HAART

HIV

ICASO

IDASA

IMF

INGO

JHTTT

LACCASO
Associação Brasileira Interdisciplinar de AIDS (Brazilian Interdisciplinary AIDS Association)

AIDS Coalition to Unleash Power (United States)

Acquired Immune Deficiency Syndrome

African National Congress (South Africa)

Antiretrovirals (antiretroviral drugs)

Antiretroviral Therapy / Treatment

Brazilian Sexually Transmitted Diseases/AIDS Programme

Conselho Empresarial Nacional de AIDS (National Business

AIDS Council) (Brazil)

Comissão Nacional de AIDS (National AIDS Commission) (Bra-

zil)

Consumer Project on Technology (United States)

Enhancing Care Initiative (South Africa)

European Union

Grupo de Apoio à Prevenção à AIDS (AIDS Prevention Support Group) (Brazil)

Global Fund to Fight AIDS, Tuberculosis and Malaria

Global Health Governance

German Institute of Global and Area Studies

Gross National Income

Grupo Pela Valorização, Integração e Dignidade do Doente de Aids (Group for Appreciation, Integration and Dignity of AIDS Patients) (Brazil)

Deutsche Gesellschaft für Technische Zusammenarbeit (German Technical Cooperation)

Highly Active Antiretroviral Therapy

Human Immunodeficiency Virus

International Council of AIDS Service Organisations

Institute for Democracy in South Africa

International Monetary Fund

International Non-Governmental Organisation

Joint Health and Treasury Task Team (South Africa)

Latin American and Caribbean Council of AIDS Service Organisations 


$\begin{array}{ll}\text { MAP } & \text { Multi-country AIDS Programme (World Bank) } \\ \text { MNC / MNCs } & \text { Multinational Company / Companies } \\ \text { MSF } & \text { Médecins Sans Frontières } \\ \text { MTCT } & \text { Mother-To-Child Transmission } \\ \text { MP } & \text { Member of Parliament } \\ \text { NGO } & \text { Non-Governmental Organisation } \\ \text { OECD } & \text { Organisation for Economic Co-operation and Development } \\ \text { PAHO } & \text { Pan American Health Organisation } \\ \text { PEPFAR } & \text { President's Emergency Fund for AIDS Relief (United States) } \\ \text { PhRMA } & \text { Pharmaceutical Research and Manufacturers of America } \\ \text { PMA } & \text { Pharmaceutical Manufacturers Association (South Africa) } \\ \text { SANAC } & \text { South African National Aids Council } \\ \text { STD } & \text { Sexually Transmitted Disease } \\ \text { SUS } & \text { Sistema Único de Saúde / Unified Health System (Brazil) } \\ \text { TAC } & \text { Treatment Action Campaign (South Africa) } \\ \text { TRIPS } & \text { Trade-Related Aspects of Intellectual Property Rights } \\ \text { UNAIDS } & \text { Joint United Nations Programme on HIV/AIDS } \\ \text { USAID } & \text { United States Agency for International Development } \\ \text { UNDP } & \text { United Nations Development Programme } \\ \text { WHO } & \text { World Health Organization } \\ \text { WTO } & \text { World Trade Organization }\end{array}$




\section{Introduction}

HIV/AIDS has emerged as a global epidemic of hitherto unknown repercussions. The most reliable statistics estimate that 40.3 million people world-wide were infected with HIV in December 2005 and that 3.1 million have died from AIDS-related diseases in the year 2005 alone (UNAIDS \& WHO 2005: 1). In correspondence to the magnitude of the epidemic, global initiatives have emerged to contain the spread of the disease and to mitigate its effects. HIV/AIDS thus can be seen as one of the triggers of Global Health Governance (GHG). At the same time, public health policies and its implementation are still generally perceived to be one of the state's domaine réservées.

Accordingly, this paper endeavours to analyse the relationship between GHG and national health governance in the case of HIV/AIDS. The interest is, first, to assess the impact of GHG on the national level and, second, in the other direction, the influence of national health governance on GHG. This paper will compare Brazil and South Africa as two cases in which the relationship between national politics and GHG has been structured in contrasting ways, ranging from conflict to cooperation. Different reciprocal influences will be analysed through the interface concept formulated by the GHG project group of the German Institute of Global and Area Studies (GIGA) (Hein, Bartsch \& Kohlmorgen 2006; Bartsch \& Kohlmorgen 2005; Hein \& Kohlmorgen 2003). Interfaces are defined as "as socio-political spaces of recurrent interactions of collective actors in the handling of transnational and international affairs" (Hein, Bartsch \& Kohlmorgen 2006: 14). These forms of interaction can either take conflictive or cooperative forms. A differentiation is made between four kinds of interfaces:

1. "resource-transfer interfaces" denote the exchange of material and immaterial resources. A typical example in the context of a developing country is the provision of development assistance by the World Bank or, bilaterally, by developed countries.

2. "organisational interfaces" stand for formal and informal organisational forms of interaction between different actors. These can be partnerships such as the Global Fund to Fight Aids, Tuberculosis and Malaria (GFATM) or non-formalised means of cooperation.

3. "legal interfaces" are defined by the implementation of judiciable norms and standards. Cases before national or international courts as well as formal contracts are the most common form of legal interfaces.

4. "discursive interfaces", finally, characterise the exchange of different ideas and values of actors from the global and the national level (Bartsch \& Kohlmorgen 2005: 3). 
GHG actors interacting through the four interfaces are states, international organisations, private business and civil society.

The paired comparative analysis of this paper entails Brazil, a country where the relationship to GHG has been critical cooperative and South Africa, whose interaction with the global level has been conflictive. ${ }^{2}$ These different outcomes came about despite significant similarities in the countries' basic conditions. First, both Brazil and South Africa have major HIV/AIDS epidemics. According to Gauri \& Lieberman, "important aspects of the epidemic followed a similar initial trajectory in both countries" (2004: 2). In the mid-1980s, a major HIV/AIDS crisis was predicted for both countries. However, Brazil has been able to keep the prevalence rate at $0.7 \%$ of the population (UNAIDS 2004: 202), whereas statistics for South Africa range from $10.4 \%$ to $11.8 \%$ (Doherty \& Colvin 2004: 196). It is estimated that 660,000 people in Brazil live with HIV; which contrasts with 5.3 million South Africans estimated to be infected by HIV (UNAIDS 2004: 190-191). ${ }^{3}$

Second, besides the initial trajectory of the HIV/AIDS epidemic, both countries are middleincome countries with comparable average incomes. Brazil had a gross national income (GNI) per capita of US\$ 3,090 in 2004 and South Africa's amounted to US\$ 3,630 for the same year (World Bank 2005a: 292-293). The purchasing power parity in 2003 amounted to US\$ 7,790 for Brazil and US\$10,346 for South Africa (UNDP 2005: 267-268). Additionally, both countries are plagued by a high degree of inequality, assessed through the Gini Index. In 2001, Brazil had a Gini Index of $59.3^{4}$, which is comparable to South Africa's value of $57.8^{5}$ in 2000 (UNDP 2005: 271-272). As a country's average income tends to be highly correlated with the expenditure for fighting HIV/AIDS (Gauri \& Lieberman 2004: 2-3), both governments could potentially revert to a similar resource base for fighting the disease. Furthermore, it can be expected that the basic relationship of Brazil and South Africa as middle-income countries to GHG is comparable, whereas it fundamentally differs from least developed countries and from industrialized countries of the "North".

Thus, on two fundamental context variables Brazil and South Africa exhibit commonalities, whereas they differ on the outcome, i.e. their relationship to GHG. The starkest differences in their fight against HIV/AIDS can be seen in respect to the antiretroviral (ARV) treatment of

\footnotetext{
${ }^{2}$ To our knowledge, Gauri and Lieberman (2004) have been the only scholars who have compared Brazil and South Africa in the field of HIV/AIDS policy. They, however, focused on the two countries' response to the epidemic in general and not on the relationship between GHG and national health governance. Accordingly, the comparison in this paper aims at providing new insights on the political mechanisms related to GHG and the national level.

${ }^{3}$ Note that due to methodological differences, the Brazilian and South African figures are not completely comparable.

${ }^{4}$ Based on income.

${ }^{5}$ Based on consumption.
} 
HIV-infected people. The Brazilian government started to rollout ARVs free of charge in 1996; whereas South Africa - reluctantly - only started in 2003, eight years later. ${ }^{6}$ This two-N comparison will thus provide insights on the influence of GHG on national HIV/AIDS governance and vice versa.

The qualitative comparison rests on a wide range of primary and secondary sources as its empirical base. We conducted 48 interviews in South Africa and 68 in Brazil ${ }^{7}$, with respondents coming from governments, international organisations, the private business sector, civil society organisations, the medical and the scientific sector. The analysis in this paper evolves along the four interface-types set out above, i.e. resource-transfer, organisational, legal and discursive. On the basis of the analysis along the four interface types the concluding chapter unravels the conflict and cooperation between national health governance and GHG in the fight of HIV/AIDS in Brazil and South Africa.

\section{Resource-transfer Interfaces: Different Degrees of Autonomy from the Global Level}

This study operationalises resource-transfer interfaces through external financial support for national health governance in the sphere of fighting HIV/AIDS. Resources can come from multilateral and bilateral donor agencies as well as from private foundations. They might direct their funds to state organisations or to the civil society.

In 1982, the year in which the first case of AIDS was made public in Brazil, the country also became heavily affected by the Latin American debt crisis (Baer \& Paiva 1996: 67-8, 71; for an overview see Sangmeister 1992: 255-6). ${ }^{8}$ Only with a debt restructuring agreement and the issuing of federal bonds the severe financial crisis was resolved in 1994 (Calcagnotto 1985: 63-74; Vazquez 1996: 5; Fritz 2002: 132-134; Tesouro Nacional 2006: 1-2). Thus, at least until the mid-1990s, Brazil had been reliant on resource-transfer interfaces for funding from the global level.

\footnotetext{
${ }^{6}$ The South African government has for a long time fiercely resisted the rolling-out of antiretrovirals (ARV) in public hospitals for the prevention of mother-to-child transmission (MTCT) of the HI virus and for treating HIVinfected people. Recent media reports suggest that despite the 2003 decision to provide ARVs the conflict over the treatment of HIV/AIDS in South Africa is not over. The number of patients on ARVs is far behind schedule and the Minister of Health does not distance herself from actors such as the Rath Foundation, which claim that ARVs are toxic (Mail \& Guardian 2005a; Sunday Independent 2005).

${ }^{7}$ Field work in South Africa was conducted from 2-25 May, 2005. Interviewers were Christian von Soest, Martin Weinel and Gero Erdmann. Gilberto Calcagnotto conducted field research in Brazil from 6 August to 29 September, 2004 and 5-27 June, 2005.

${ }^{8}$ According to Brazilian Central Bank, the middle- and long-term debt amounted in 1982 to US\$ 83,3 billion (Central Bank 1983: 93).
} 
Parallel to the general controversy about structural adjustment (Elmendorf \& Roseberry 1993: 123; Lurie et al. 1995: 539-546), the financial need for a reform of the Brazilian public health system had been unquestionable. The democratic Constitution of 1988 gave legal recognition to the principles of universal health care, decentralisation and popular participation as the fundamentals of the new Unified Health System (SUS - Sistema Único de Saúde). Accordingly, in 1989 a tax-financed public health system ("Beveridge model") replaced the former social insurance model. According to Mercadante, this institutional shift from a health system dimensioned for 90 million Brazilians to a new public health system "with current responsibilities for 160 million people today cannot be done without significant new resources" (2002: 275; see also: PAHO 2005: 27; Piola \& Biasoto 2001: 219-220; Giovanella \& Porto 2004: 11$13)$.

Since 1983 already, advocacy groups of homosexual men from São Paulo had fiercely fought for a response to HIV/AIDS following the same principles of universal access which characterised the Unified Health System. In turn, São Paulo became the pioneer of an integrated concept of HIV/AIDS care and prevention as a matter of peoples' right to health (Teixeira 1997: 46). This strategy also formed the basis of the first Brazilian AIDS Programme which was established in 1985 (Gauri \& Lieberman 2004: 18). However, although it would have conceptually been "a very proper vehicle for comprehensive management of HIV" (Berkman et al. 2005: 1166), the Unified Health System still being in its infancy could not cope with the quickly mounting HIV/AIDS epidemic.

The universal provision of treatment against opportunistic diseases (since 1988), of the antiretroviral drug AZT (since 1991) and of the antiretroviral combination therapy HAART ${ }^{9}$ (since 1996) free of charge through the national government (Galvão 2002: 214) had subsequently increased the gap between rapidly growing needs for treatment and Brazil's scarce financial resources. Calculations from 1989 estimated the direct treatment costs for each AIDS patient to be approximately US\$ 15,670 per year, with total costs forecasted to amount to around US\$ 3.5 billion for the treatment of all known AIDS patients in Brazil (Medici 1994: 328). ${ }^{10}$ Accordingly, external financing for the Brazilian Sexually Transmitted Diseases/AIDS Programme (BSAP) had become a necessity in the beginning 1990s.

In 1992, the Brazilian government was finally willing "to seek for" as the World Bank termed it (2005b: 11), or "to accept a financial help initiative offered as a long-term credit by the

\footnotetext{
${ }^{9}$ HAART stands for Highly Active Antiretroviral Therapy, a combination of three different antiretroviral drugs to treat HIV/AIDS.

${ }^{10}$ According to Oliveira \& Esher, from 1996 to 2002 the expenditures for purchasing ARV increased from US\$ 40 million to US\$ 534 million, which was due to the rising number of HIV-infected people on treatment. This increase has more than compensated the progressively declining unit prices of ARV (2004: 243).
} 
World Bank" (Galvão 2000: 140, emphasis by the authors). Since the conclusion of the loan agreement in 1994, it has been the multilateral institution that provides the highest external resource for the Brazilian health sector. Indeed, the World Bank has been "the earliest [external donor] to become involved in a major way" (2005b: 26). Through the loans AIDS I (19941998) and AIDS II (1998-2003) the institution made available credit facilities with a total of US\$ 325 million for prevention activities, epidemiological surveillance and capacity building. The Brazilian government's own contribution to the projects has been US\$ 225 million. The third programme, AIDS III (2003-2006), has a total volume of US\$ 200 million, with 50\% financed by each partner respectively (World Bank 2004: 7-9; World Bank 2005b: 14-15, 20$21,25)$ The financial contribution of other external donors has not gone beyond $10 \%$ of overall external resources (US\$ 278 million for 1992-1997) (Fontes 1999: 96-7).

Resource-transfer interfaces have also been strongly used by NGOs working in the field of HIV/AIDS. Before the World Bank started to provide funds to NGOs in 1994, financing from private foundations such as the Ford Foundation had been of "fundamental" importance for the pioneer NGOs ABIA, GAPA, and Pela VIDDA ${ }^{11}$ (Galvão 2000: 134). Today, their main revenue sources are internal as well as external. In a recent survey of 328 HIV/AIDS civil society organisations, the greatest group stated to receive funds through "agreements with public bodies" (78\%) and "donation by individuals" (72.6\%). However, $40.9 \%$ also draw on support from an "international cooperation agency" (Castro \& Silva 2005: 157).

In conclusion, Brazil has extensively used resource-transfer interfaces in relating to GHG. Since the World Bank loans were issued in 1993, the Brazilian Sexually Transmitted Diseases/AIDS Programme (BSAP) to a large extent has been funded by external sources. Furthermore, the civil society organisations working on HIV/AIDS have also drawn on revenue sources from the global level.

In contrast, South Africa's fight against HIV/AIDS was hardly directly influenced via financial contributions from the global level - that is resource-transfer interfaces. According to Schneider \& Gilson (1999: 266) total international aid to the health sector had just been over $1 \%$ of the South African annual government health budget in the period 1994 until 1999 and did not rise thereafter. As a middle-income country which has not been severely indebted ${ }^{12}$, South Africa has not been reliant on conditional donor aid. ${ }^{13}$ Neither the Apartheid govern-

\footnotetext{
${ }^{11}$ GAPA is the abbreviation for Grupo de Apoio à Prevenção à AIDS (AIDS-Prevention Promotion Group); Grupo Pela VIDDA stands for Grupo Pela Valorização, Integração e Dignidade do Doente de Aids (Group for Appreciation, Integration and Dignity of AIDS Patients).

${ }^{12}$ In 1996, shortly after the democratic transition, South Africa's total external debt amounted to US\$23.6 billion (World Bank 1998: 249).

${ }^{13}$ Accordingly, this position stands in clear contrast to Brazil.
} 
ment nor, since the democratic transformation in 1994, the African National Congress (ANC) government have extensively drawn on external resources for financing public health policies. ${ }^{14}$ In correspondence to its favourable financial position, the ANC-government thus has refused offers of financial or technical aid which it found not fitting into its policy framework, "particularly from the World Bank" (Gauri \& Lieberman 2004: 28) and particularly in respect to the controversial question of HIV/AIDS treatment.

This approach became obvious when in 2002 the ANC-government blocked the disbursement of US\$ 72 million which the Global Fund to Fight AIDS, Tuberculosis and Malaria (GFATM) had awarded to the Enhancing Care Initiative (ECI) of the province KwaZuluNatal. Its HIV/AIDS programme inter alia included antiretroviral schemes to reduce the risk of mother-child-transmission (MTCT) of the virus and to provide antiretroviral treatment to infected persons (Pawinski \& Lalloo 2002). Despite the fact that the South African National AIDS Council (SANAC) had not been functioning at that time, the Minister of Health argued that only the national government level could apply to the Global Fund (Weinel 2005: 45). Only in March 2004, the approved funds were - through the national government - transferred to KwaZulu-Natal's Enhancing Care Initiative (information given by a respondent interviewed for this study). ${ }^{15}$

Inflows of foreign aid were only accepted in 2004 also, with the US-American President's Emergency Fund for AIDS Relief (PEPFAR) providing US\$ 89.4 million during the year and US\$ 132.1 million in 2005 for treatment, prevention, care of orphans and palliative care (United States Global AIDS Coordinator 2005: 115). ${ }^{16}$ As stated by the US embassy in South Africa, $60 \%$ of the funds have been allocated to the South African government and $40 \%$ to civil society organisations working in the field of HIV/AIDS (United States 2006). However, the influence on South Africa's HIV/AIDS policy is perceived to be low as the ANCgovernment integrates PEPFAR funds according to its strategies already in place. The funds thus cover parts of government programmes (Interview Ramlagan, 11.05.2005).

A lot of South African civil society actors have been partly or fully funded by external actors such as aid agencies, international organisations or private foundations. Recipients have been for instance the Treatment Action Campaign (TAC), the Health System Trust, the AIDS Foundation or the research institute IDASA. Most prominent has been the TAC, which since its foundation in December 1998, has quickly emerged as the most vocal civil society actor in

\footnotetext{
${ }^{14}$ Due to an international embargo, the opportunities for the Apartheid government to draw on external funds had been limited in any event.

${ }^{15}$ The name of the respondent was made anonymous.

${ }^{16}$ According to the US embassy in South Africa, the funds allocated in the year 2005 have amounted to US\$ 148 million (United States 2006).
} 
the sphere of South Africa's HIV/AIDS policy. ${ }^{17}$ Almost the total of the organisation's R23.5 million budget for the financial year ending in February 2005 came from foreign donors. The sources among others were Bread for the World, the Open Society Foundation, the Swedish International Development Agency, Oxfam and the Ford Foundation. Only one donator, the AIDS Foundation of South Africa is based in the country (TAC 2005). ${ }^{18}$ Less obvious has been the resource-transfer from international organisations. Despite the fact that the TAC lists UNAIDS as one of their donors, it remains unclear how much resources UNAIDS has indeed provided to TAC and for what activities (Mbali 2005: 38). Furthermore, despite the fact that TAC as well as respondents from international organisations interviewed for this study reported regular interaction, the status of UNAIDS, WHO, GFATM as international organisations prevented them from openly criticising the South African government and aligning with TAC or other civil society actors. ${ }^{19}$

Direct resource-transfers to South Africa's HIV/AIDS programme have been low. The prime reason has been the ANC-government's resilience to preserve its national sovereignty. The status as a middle-income country with insignificant external debt has allowed the government to refuse external aid. There has been, however, strong interaction through resourcetransfer interfaces between South Africa's NGOs and the global level. In respect to these actors, the influence of GHG on national health governance can be perceived to be strong.

\section{Organisational Interfaces: Important Indicator for Conflict and Cooperation}

In this study, organisational interfaces are defined as entities, which are formed by at least two consenting actors from GHG and national health governance. The use of organisational interfaces therefore acts as a crucial indicator for the degree of cooperation between the national and the global level.

Since 1980, the World Health Organization (WHO), through its regional representative Pan American Health Organisation (PAHO), has developed multiple initiatives with Brazilian health authorities and academic institutions. These joint activities by means of organisational interfaces laid the conceptual basis for the reform of Brazilian health system in the 1980s and

\footnotetext{
${ }^{17}$ Some commentators even describe the TAC as "one of South Africa's most effective and active" groups in the whole NGO sector (Mail \& Guardian 2003; see also Willan 2004: 114).

${ }^{18}$ The full list of donors along with a detailed analysis can be found in Mbali (2005: 22-23).

${ }^{19}$ GFATM's 2002 decision to grant US\$ 72 million to KwaZulu-Natal's HIV/AIDS programme, which also entailed funds for ARV treatment, can be understood as an implicit support for an antiretroviral treatment strategy against HIV/AIDS in South Africa (see below and also Weinel 2005: 45).
} 
1990s. As outlined above, this in turn shaped the Brazilian Sexually Transmitted Diseases/AIDS Programme (BSAP) (Lima 2002: 92-93; Fontes 1999: 113-114).

The UNAIDS Theme Group on HIV/AIDS, established in Brazil in 1997, has coordinated the activities of international organisations in the country. It includes various UN organisations, the World Bank, bilateral donor organisations, the BSAP and the Foreign Ministry, as well as two representatives from civil society (UNAIDS 2001: 3). Since 2004, several other federal ministries have also used this organisational interface (Interview Herlt, 13.9.2004). According to the former Director of BSAP, Paulo Teixeira, the UNAIDS Theme Group in Brazil has brought "positive synergic effects" at federal, state and municipal levels (Interview Teixeira, 24.8.2004). It has actively participated in the organisation of the Brazilian HIV/AIDS prevention campaign, for instance through motivating local mayors to actively participate and inform their communities on the epidemic (Interview Milhomem, 15.9.2004). However, UNAIDS' interaction with the WHO and World Bank has been rather formal than effective and the exchange with other national institutions working on HIV/AIDS prevention and treatment has almost been non-existent. Accordingly, UNAIDS and WHO have rarely exerted a direct influence on the formulation of the Brazilian HIV/AIDS policy (Interviews Teixeira, 24.8.2004; Bonifácio, 14.9.2004).

Conversely, Brazilian actors effectively used organisational interfaces to influence GHG. In 2004, Brazil's representative was unanimously elected Vice-President of the UNAIDS Programme Coordinating Board and in 2005 he assumed the Presidency of the body (CNAIDS 2004). This increased impact on the global level exemplifies the government's general policy of actively working on HIV/AIDS within international organisations. There have also been evidences for Brazil's civil society exerting influence on GHG. For instance, the 1986founded Brazilian Interdisciplinary AIDS-Association (ABIA) was actively involved in the fifth International AIDS Conference in Montreal in 1989 (Galvão 2000: 87). On that occasion, the International Council of AIDS Service Organisations (ICASO) was established with the main aim to strengthen the global response of civil society organisations. Acting as the ICASO Secretariat for Latin America, ABIA also spearheaded the creation of the Latin American and Caribbean Council of AIDS Service Organizations (LACCASO) as a further organisational interface (Galvão 2000: 87). ${ }^{20}$

In the context of organisational interfaces, the active participation of NGOs and the Brazilian government on GHG appears to have been of more importance than the direct influence of multilateral organisations, such as UNAIDS, onto Brazil's national health governance.

\footnotetext{
${ }^{20}$ In Galvão (2000), further examples of Brazilian NGOs entering into organisational interfaces can be found.
} 
WHO's influence through organisational interfaces, for example, has been important for the fundamental reform of the Brazilian Unified Health System but less for the fight against HIV/AIDS specifically.

In contrast, the South African government rarely entered into organisational interfaces, indicating a high degree of conflict with the GHG level, particularly in respect to antiretroviral treatment of AIDS. One important organisational interface between the global and the national level has been LoveLife, an organisation working in the field of HIV/AIDS prevention. The public-private partnership has been co-financed by the US-based Kaiser Family Foundation and other donors as well as the South African government, which provides $34 \%$ of the overall budget. Furthermore, LoveLife receives substantial resources from the Global Fund. ${ }^{21}$ The organisation's annual budget for 2005 has been around R200 million (Interview O'Connor, 11.05.2005; Mail \& Guardian 2005b). Running South Africa's biggest HIV/AIDS prevention programme for teenagers, it designs accessible and youth friendly clinics, advertising campaigns, and sponsors various events (Interview O'Connor, 11.05.2005). LoveLife enjoys a cordial and collaborative relationship with the government and even has the Minister of Health on its Advisory Board. In short, it acts as a "government service-provider" (Mbali 2005: 18).

Furthermore, there is some evidence that experts from the William J. Clinton Foundation were involved in the Joint Health and Treasury Task Team (JHTTT), which was set up to investigate the feasibility and the costs of universal access to treatment of HIV/AIDS in South Africa in 2002 (Ijumba et al. 2004: 333). The US foundation was thus linked to the national level through an organisational interface. However, it remains unclear how far-reaching the technical support and the practical influence of the Clinton Foundation's experts on South Africa's “Operational Plan for Comprehensive HIV/AIDS Care, Management and Treatment for South Africa" (Government Communication and Information Service 2003) in fact had been. Although the Clinton Foundation was - on the global level - very influential in reducing prices for antiretroviral drugs, their experts were later denied further access to South African institutions with the government stopping any further cooperation with the foundation (information given by a respondent interviewed for this study). ${ }^{22}$

A prominent organisational interface which global actors required for accessing their funds has been the South African National AIDS Council (SANAC). Although the Partnership against HIV/AIDS, introduced by the then Deputy President Mbeki in October 1998, could be interpreted as a move towards a broad-based response to the HIV/AIDS epidemic, SANAC,

\footnotetext{
${ }^{21}$ It thus also is an example for the resource-transfer interface.

${ }^{22}$ The name of the respondent was made anonymous.
} 
founded in January 2000, was the first South African institution that embodied the idea of a "multisectoral response",23 (Strode \& Barrett Grant 2004: 14). Shortly after its inception, the Multi-country AIDS Programme (MAP) of the World Bank, launched in September 2000, requested countries to formulate a "coherent national, multisectoral strategy and action plan" and to apply for grants through "a high-level HIV/AIDS coordinating body - that is a national AIDS commission or council” (Putzel 2004: 1131-1132.

South Africa did not participate in MAP, but aimed at applying for Global Fund grants. The government even sent the Vice-Minister of Health as a representative to the Board of the organisation. Similarly, the Global Fund, created in 2002, made a particular organisational structure, the "Country Coordinating Mechanism" an institutional necessity for the disbursement of its funds. As shown in the discussion of the Enhancing Care Initiative in KwaZuluNatal, SANAC, the South African version of the coordinating body, started functioning only in early 2002. An obvious interpretation is that SANAC has first and foremost acted as the required "Country Coordinating Mechanism" in order to access resources from the Global Fund, while it has not fulfilled its functions prescribed in the 2000-2005 Strategic Plan. ${ }^{24}$ Thus, in this case, resource-transfer considerations induced the South African government to form an institution along a globally prescribed "organisational template" (Putzel 2004: 1130). On the whole, the South African government rarely entered into organisations with international actors in the fight against HIV/AIDS. Examples found have worked on HIV/AIDS prevention, with LoveLife being the most prominent organisation. The short cooperation episode with the Clinton Foundation strongly confirms the government's stance to preserve its autonomy. In the face of South Africa's treatment controversy, the government has not been willing to accept external influences through organisational interfaces.

\section{Legal Interfaces: Disputes with Repercussions for the Global Level}

Legal interfaces are one of the main means broadening or narrowing the access to the public health system. Therefore, the legal recognition of the 1988 Brazilian Constitution to universal access to health as "a right of all and a duty of the State" (Republic of Brazil 1988, Art. 196 in: Senado Federal 2003: 119) had acted as an immovable pillar for the negotiations about the World Bank credits AIDS I-III (Parker et al. 2001: 110). On the global level, Brazil's fight for

\footnotetext{
${ }^{23}$ A "multisectoral" approach in fighting HIV/AIDS entails the involvement of all branches of government and cooperation with non-governmental actors (World Bank 1999: 22-23; Putzel 2004: 1134-1135).

${ }^{24}$ The regulative base of SANAC is laid down in the Strategic AIDS Plan 2000-2005 (Department of Health 2000: 12-14), which was developed during the second half of 1999.
} 
a human right to access antiretroviral treatment was indirectly recognised by the April 2001 Resolution of the UN Commission on Human Rights dealing with the "Access to medication in the context of pandemics such as HIV/AIDS." The resolution was passed by a 52-0 vote with only one abstention (Wogart \& Calcagnotto 2006: 96; Galvão 2002: 219). One month later, the WHO World Assembly, following a Brazilian proposal, also confirmed "the right to health and that the progressive realisation of that right in the context of HIV/AIDS involves access to treatment" (ISHR 2001).

However, coming to GHG influencing national health governance, Brazil has for a long time fought with the United States over pharmaceutical patent rights. PhRMA, the association of the US pharmaceutical industry, had started to lobby against the Brazilian patent law, which excluded medical products from patent protection, already in 1988 (Marques 2002: 43, Tachinardi 1993: 67). Only following severe commercial sanctions through punitive customs duties on selected Brazilian export products ${ }^{25}$, applied in 1990 (Silva 2005: 131), the Brazilian government consented to formulate a patent law which included the protection of pharmaceutical products. However, the new Brazilian patent law, issued in 1996, still limited the scope of pharmaceutical patent rights. Paragraph 68 forced pharmaceutical MNCs to locally produce their drugs within three years of patent approval - a provision whose non-compliance allowed the government to issue compulsory licences. ${ }^{26}$ The United States filed a complaint on this Paragraph with the WTO in 2001 (Galvão 2002: 216; Marques 2002: 44, 46).

The dispute, fought through legal interfaces, only came to end when Brazil restricted the possibility of compulsory licensing to cases of a national health emergency. In consequence, the United States on June 25, 2001, withdrew its formal complaint against Brazil before the WTO. Brazil in turn agreed to notify the US government in advance if it found it necessary to issue a compulsory license. This solution came also as a result of open pressure from NGOs, simultaneously articulated through discursive interfaces in the US and Brazil (Cepaluni 2005: 80-81; Ashraf 2001: 2112; Galvão 2002: 215-6; Wogart \& Calcagnotto 2006: 95-96).

Since 1997, a Brazilian state laboratory (Far-Manguinhos in Rio de Janeiro) has developed the technology for the production of several ARV combinations which consisted of drugs non-protected and of drugs protected by patent laws (Oliveira \& Esher 2004: 244; Cassier \& Correa 2003: 90-91; Marques 2002: 69). For the latter, the pharmaceutical MNCs as patent holders were allowed to and indeed did charge monopoly prices. As a consequence, the Brazilian authorities in the early 2000s had negotiated with a number of pharmaceutical MNCs in

\footnotetext{
${ }^{25}$ These were for instance electronic, pharmaceutical and chemical products, as well as paper and cellulose.

26 "Compulsory licensing is generally defined as the granting of a license to a third-party by a government to use a patent without the permission of the patent holder" (Kühl 2002: 17).
} 
order to obtain cheaper prices for the ARV cocktail (Oliveira \& Esher 2004: 244-245; Wogart \& Calcagnotto 2006: 96). Following unsuccessful negotiations, the Brazilian Health Minister in August 2001 announced that his government would issue a compulsory license for the production of Roche's antiretroviral drug Nelfinavir (sold under the brand name Viracept) to a Brazilian manufacturer. Responding to the threat, Roche resumed the negotiations and agreed to lower its prices by $40 \%$ (Roche 2001). The threat of issuing compulsory licenses for generic drugs brought substantial price cuts for other antiretroviral drugs as well (Cohen \& Lybecker 2005: 218-220). ${ }^{27}$

Along this "Brazilian path", the government has used legal interfaces in different ways: Its strategies have ranged from open conflict to pragmatic negotiations with pharmaceutical MNCs. After the negotiations' collapse, the government overtly threatened to use the legal provisions for compulsory licensing. There thus have been numerous empirical evidences emanating from the Brazilian case that legal interfaces are a particularly strong weapon to enhance public health interests both at the global and the national level.

In the South African case, legal interfaces, used by global and national actors, have also been important forms of interaction with repercussions for GHG. South Africa came in the international limelight when in February 1998 the Pharmaceutical Manufacturers Association of South Africa (PMA), backed by the American PhRMA, sued the South African government for violating their property rights before South Africa's High Court. ${ }^{28}$ The lawsuit, which was based on the legal provisions of the TRIPS Agreement, was supported by the United States government, which threatened to impose trade restrictions on South Africa (Lanoszka 2003: 191-192).

It aimed at the Medicines and Related Substances Control Amendment Act, signed by President Mandela in December 1997, which gave the South African Minister of Health the power to allow both compulsory licensing and parallel importation ${ }^{29}$ of patented medicines, in this case particularly antiretroviral drugs (Kühl 2002: 76). Responding to intense national and international public pressure and with only slim chances to win the case, the 39 pharmaceutical MNCs represented by the PMA backtracked from the case in late 1998 (Weissman 2001).

\footnotetext{
${ }^{27}$ The domestic production of the drugs Nevirapine and Indinavir in 2000 represented savings of US\$ 80 million, or 30\% of the overall ARV-expenditures in that year (Marques 2002: 69). As a consequence of price reductions and local production of non patented ARVs, US\$ 960 million were saved between 1996 and 2002 (Oliveira \& Esher 2004: 245)

${ }^{28}$ See particularly paragraph 2.4 of the complaint with the High Court (PMA 1998). Extensive documentation of the case can be found on the web page of the American NGO CPtech (http://www.cptech.org/ip/health/sa/).

29 "Parallel importation refers to the imports of goods purchased in a foreign market by an independent third party and later resold in the domestic market where much lower prices compete with the prices charged by authorized distributors" (Kühl 2002: 18).
} 
However, in January 2001 the lawsuit was reinstated. The chances for a victory of the pharmaceutical manufacturers were considerably better because South Africa was now obliged to fully comply with the requirements of the TRIPS Agreement (Kühl 2002: 76). The pharmaceutical MNCs maintained that the case was not directed against South Africa's efforts to seek price reductions for antiretroviral medicine. That, however, was exactly the impression that AIDS activists and NGOs in South Africa and around the world tried to create. Internationally recognised NGOs such as Médecins Sans Frontières, Oxfam, CPtech or ACT-UP pressured the pharmaceutical MNCs to withdraw the case. Even the Bush administration now refrained from openly supporting the pharmaceutical industry (Weissman 2001). Demonstrations were organised in South Africa, but also in front of several pharmaceutical MNCs' headquarters in Europe and North America.

The pharmaceutical industry, fearing another public relations nightmare, finally withdrew the lawsuit in mid-April 2001 (Lanoszka 2003: 192) and agreed to "a settlement almost on the government of South Africa's terms. The only concession made by the government was to comply with decisions made by the World Trade Organizations on TRIPS” (Kühl 2002: 78). Therefore, the Medicines and Related Substances Control Amendment Act from 1997 remained largely unchanged. In conjunction with strong public pressure from discursive interfaces used, the legal challenge was averted. However, the government rejected proposals from civil society to declare the HIV/AIDS epidemic a national emergency. ${ }^{30}$ The Doha Declaration explicitly permits countries to issue compulsory licences in case of national health emergencies (Gauri \& Lieberman 2004: 26).

On balance, legal interfaces, through the High Court case, have been an important route for interaction of South African actors and the global level. It strengthened the South African government's case of blaming pharmaceutical MNCs and augmented the international pressure to reduce the prices for antiretroviral drugs. The legal interfaces are the means of interaction in which the strategies of the Brazilian and the South African governments have shown the biggest similarity. Both governments have fought against pharmaceutical MNCs being responsible for high ARV-prices. According to Gauri and Lieberman, both countries "have styled themselves as emboldened leaders of the developing countries in this regard" (2004: 27).

\footnotetext{
${ }^{30}$ In fact, the obvious contradiction between the South African government claiming that antiretrovirals are too expensive and not using its legal provisions to lower the prices remains puzzling. One common explanation given from respondents in South Africa has been that the ANC-government does not perceive the HIV/AIDS epidemic to be a national emergency. One MP from the ruling party and member of SANAC maintained that "we are not running in a crisis mode."
} 


\section{Discursive Interfaces: Strong Interaction between National and Global Level}

The loan negotiations between Brazil and the World Bank (see resource-transfer interfaces) took place amidst a dispute, expressed through discursive interfaces, of the Brazilian government focussing on its comprehensive and human rights-based approach to fight HIV/AIDS on the one hand and the World Bank with its prevention concept on the other hand. The role of NGOs in the negotiations helped to restrict the World Bank's influence to an almost exclusively resource-transfer character. In fact, as Parker et al. remark,

Brazil's experience in fighting AIDS did not orient itself accordingly to the ideas the Bank offered. On the contrary, Brazilian government developed the experience to guarantee universal access of AIDS patients to ARV, and this experience - because of its innovative characteristics - has been discussed and taken as an example for other countries (2001: 110).

For the World Bank, drug distribution without charging patients has not constituted a policy to be recommended, since the institution focussed on the cost effectiveness of public health programmes (1997: 3). Nevertheless, these differences on the discursive level did not impede the concession of the AIDS I-III loans, because both sides "agreed to disagree" (World Bank 2005b: 13). Brazil's comprehensive approach could be implemented, whereas the World Bank invested in improving the cost effectiveness of HIV/AIDS prevention, surveillance and in building public health institutions. The disagreement on discursive aspects did thus not prevent an agreement about financial cooperation.

HIV/AIDS workplace programmes may also be considered to influence through discursive interfaces, since they raise awareness for the epidemic, inform about prevention and demonstrate the effectiveness of ARV treatment. In Brazil, workplace programmes for prevention and awareness have been implemented since 1985, with large national and multinational companies taking the lead. Bank conglomerates (e.g. Itaú since 1987), state owned companies (e.g. the power utility Furnas since 1992) and MNCs such as Ford have implemented HIV/AIDS awareness and prevention programmes from early on (Terto 1997: 142, 152; Teixeira 1997: 60-61). NGOs such as ABIA and GAPA as well as immunology centres, which never had any direct contact to the business sector before, have provided technical input to companies' HIV/AIDS workplace programmes (Terto 1997: 152). ${ }^{31}$

Established in 1998, the Brazilian National Business AIDS Council (CEN) has been the body representing business at the Brazilian Sexually Transmitted Diseases/AIDS Programme (BSAP). It furthermore has exerted an important global diffusion function in disseminating best practices in respect to workplace programmes (Terto 1997: 154). The result of these do-

\footnotetext{
${ }^{31}$ This also acts as an example for organisational interfaces.
} 
mestic and multilateral activities has been a change in mentality. Firms and private foundations began to view NGOs and trade unions as potential partners in fighting HIV/AIDS. One scholar even speaks of a "new social philanthropy" on the part of the business sector (Terto 1997: 152). However, quantitatively the picture is less encouraging: According to a 2006 World Economic Forum survey, only $43 \%$ of 212 Brazilian business leaders interviewed declared that their company runs a workplace HIV/AIDS programme (BBC Brazil 2006).

In sum, the position of the BSAP focussing on comprehensively fighting HIV/AIDS, i.e. integrating prevention, care and treatment, has originated as a result of domestic pressure from civil society organisations. Apart from the question of antiretroviral drug pricing, the interaction between Brazil's national health governance and GHG through discursive interfaces has been critical cooperative. ${ }^{32}$ The HIV/AIDS workplace programmes have exemplary shown the consensual use of discursive interfaces between multinational and national businesses as well as NGOs in fighting HIV/AIDS in Brazil.

In South Africa, discursive interfaces have been characterised by conflicts between the South African government and global as well as other national health governance actors. Global actors operating in the country have, however, increasingly been successful in shaping discourses on HIV/AIDS and on antiretroviral treatment in particular. Contradicting government positions, they were able to demonstrate that antiretroviral treatment of HIV/AIDS is an effective and feasible option for the country.

One of the most prominent HIV/AIDS antiretroviral projects emerged in the Western Cape, the only province which, besides KwaZulu-Natal, had not been governed by the ANC until 2004. In January 1999, the Nobel Peace Prize winning NGO Médecins Sans Frontières (MSF) started - with the support of the Western Cape provincial government - an ARV-based programme to reduce the risk of mother-to-child transmission (MTCT) in Khayelitsha, a large township close to Cape Town (Médecins Sans Frontières 2003: 14). In May 2001, the organisation established the first public sector service to provide antiretroviral treatment to people living with HIV/AIDS in South Africa. Although the national government disapproved this development, the political constellation in the Western Cape province permitted the engagement of MSF. The Khayelitsha project set a publicly visible example that antiretrovirals can be successfully administered even in a resource-poor setting of a township. This is reflected in a report of the TAC - a close ally of MSF - from 2003:

\footnotetext{
${ }^{32}$ As shown above, that did not preclude different positions of Brazil's government and the World Bank on the implementation of Brazil's strategy against HIV/AIDS.
} 
The Western Cape is strategically important to TAC because it is here that the potential for good examples on treatment are most likely to be set for the rest of the country at a primary health-care level (Treatment Action Campaign 2003: 3).

The media have also used the Khayelitsha project to push the government on the provision of drugs in order to lower the risk of MTCT, with headlines like "It's so easy to save our AIDS babies" (Sunday Times 2000) or "Ray of light for HIV moms" (Sunday Times 1999).

Generally, the NGO sector strongly interacted through discursive interfaces. The TAC most actively forged networks with international non-governmental organisations (INGOS) and international organisations which have had significant impacts on GHG. ${ }^{33}$ In cooperation with its partners, TAC organised the international protests supporting South Africa's government in the court case of the Pharmaceutical Manufacturers Association challenging the Medicines and Related Substances Amendment Act (Gumede 2005: 157, see also above). INGOs later also conducted solidarity protests during TAC's civil disobedience campaign against the government, which included demonstrations in front of South African embassies around the world (Mbali 2005: 36). In its campaign tactics, TAC has learnt from the US-based NGO AIDS Coalition to Unleash Power (ACT-UP) (Schneider 2001: 18). This gives further evidence to the strong interaction of NGO actors from the national and the global level through discursive interfaces.

In contrast, scholars have described the reaction of MNCs which operate in South Africa towards the HIV/AIDS epidemic as reluctant and weak (Dickinson 2004: 628; Connely \& Rosen 2005: 1925). No coordinated and explicit initiative emerged to influence the fight against HIV/AIDS. However, there have been strong indications that concern was expressed behind closed doors. Important in this regard has been the President's International Investment Council, consisting of 15 business leaders from all over the world. According to various respondents from international organisations and business interviewed for this study, in March 2002 members of the body warned President Mbeki about the HIV/AIDS treatment controversy's possible implications for foreign direct investment to South Africa (Gumede 2005: 171). The weekly newsletter ANC Today, published after the International Investment Council meeting, acknowledged that "the members of Council had raised serious concerns about some persisting negative perceptions of our country internationally" (ANC 2002). This gave a new resource-transfer dimension to the discursive contest around South Africa's HIV/AIDS policy: it affected the country's attractiveness as a place for foreign business.

\footnotetext{
${ }^{33}$ Accordingly, this also serves as an example of organisational interfaces.
} 
More public resonance found the workplace programmes of large, often multinational, business in South Africa which have provided antiretroviral treatment to their workers and their families. Businesses' commitment to workplace programmes has been contested in the literature. Dickinson for instance argues, that most companies started to move towards the provision of antiretrovirals to their workers not earlier than 2002, when the government already began to change its stance on HIV/AIDS treatment (2004: 627, 631). Connely \& Rosen estimate that only between 5,000 and 30,000 South African workers (and in some cases members of their families) received ART in the beginning of 2005 (2005: 1925). Without entering into the discussion whether businesses' reaction has been adequate to the magnitude of the HIV/AIDS problem in South Africa, it can be safely said that the highly publicised workplace programmes of the mining company Anglo-American, the parastatal power utility Eskom and the - multinational - car manufacturers DaimlerChrysler, BMW and Volkswagen had a demonstration effect on South Africa's HIV/AIDS policy via discursive interfaces. ${ }^{34}$

In sum, discursive interfaces have been the strongest route of interaction between the South African and the global level. MSF's Khayelitsha project and (multinational) businesses' workplace programmes set a forceful and publicly visible precedent of effectively administering antiretroviral therapy. The concerns raised by MNC leaders point to economic consequences as a forceful factor amplifying discursive interfaces. Conversely, civil society actors such as the TAC successfully influenced the global level and created an international awareness for the HIV/AIDS treatment controversy in South Africa.

\section{Conclusion}

The fight against HIV/AIDS has been an area of strong national health governance and GHG interaction. Both South African and Brazilian actors have interacted continuously with the global level through different interfaces. The ways of interaction have, however, been diametrically opposed with the starkest differences in respect to resource-transfer interfaces. Brazil has, through three World Bank loans, received a total of US\$ 425 million for its National AIDS Programme, whereas South Africa has refused international assistance apart from Global Fund resources for its prevention programme. Only in 2004, the South African government accepted funds for the province KwaZulu-Natal's HIV/AIDS programme, which also entailed an antiretroviral treatment component. This contrasting receptivity for funds from the

\footnotetext{
${ }^{34}$ For case studies on workplace programmes in two large South African companies see Stevens (2004). On workplace programmes in South Africa see also Marais (2000: 30) and Butler (2005: 11). Further empirical sources have been the interviews conducted during field research in May 2005.
} 
global level exemplifies the conflicting relationship with GHG on the part of South Africa and Brazil's cooperative approach. ${ }^{35}$

This analysis has clearly shown that the influence of GHG on national health governance has been mediated by the national political context. In other words, national politics and actor constellations account for most of the contrasts between Brazil and South Africa's fight on HIV/AIDS. This concurs with Gauri and Lieberman who state that "differences in foreign assistance on HIV/AIDS can be explained from the perspective of domestic policy choices" (2004: 27, see also Gould 2005: 2).

It is beyond the scope of this paper to explain both countries' domestic policy processes but other research suggests that the decentralised nature of Brazil's political system, the more dispersed party landscape and - particularly - its coherent "national political community" incorporating all ethnicities explains much of the country's more aggressive and coherent fight against HIV/AIDS compared to South Africa (e.g. Gauri \& Lieberman 2004: 30-32). In contrast, South Africa's HIV/AIDS policy has for a long time been dominated by the central ANC-government which could push through its strict refusal to provide ARVs in the public health system. Accordingly the South African government had no interest in cooperation with GHG actors over the question of HIV/AIDS treatment and rarely entered into organisational or resource-transfer interfaces. As the dominating political actor on that national level the ANC-government severely diminished the scope for GHG influence.

Because of the conflictive relationship with GHG, discursive interfaces - with multinational NGOs and businesses for example successfully administering highly visible antiretroviral treatment programmes - became the main routes of influence in South Africa. Conversely, and somewhat paradoxically, the influence of discursive interfaces on Brazil's fight against HIV/AIDS has been lower, despite funding from the World Bank which pursued another policy. As the analysis has shown, the Bank has not been able to push through its model of how to fight HIV/AIDS. Brazil has refused to charge HIV-infected people for ARV treatment and created a much acclaimed multidimensional range of HIV/AIDS prevention and treatment activities which became known as the "Brazilian model" (Parker 2003: 144). The main reason has been the consent that had emerged on the adequate fight against HIV/AIDS among Brazilian actors from the state, civil society and business.

The analysis points to the fact that the relationship between the different interfaces is highly context-specific. On the one hand, the World Bank example has shown that interfaces can work incongruently, i.e. that accordance between national health governance and GHG actors

\footnotetext{
${ }^{35}$ Despite the fact that South Africa has - in contrast to Brazil - not heavily been indebted it seems reasonable to argue that its fight against HIV/AIDS would also have been strengthened by the acceptance of external funds.
} 
is found in respect to one interface but not in respect to an other. In Brazil's case, the resource-transfer interface was used but GHG-influence through discursive interfaces was limited. On the other hand, interfaces can work in congruence with one another. For instance, resource-transfer implications clearly stood at the basis of the South African government's decision to mould the South African National AIDS Council (SANAC) along the "organisational template" (Putzel 2004: 1130) of a country-coordinating mechanism required by the Global Fund.

Not only had GHG (some) influence on national health governance, but the national experiences and politics of Brazil and South Africa also exerted an important impact on GHG. In this direction, discursive interfaces also proved to be of crucial significance. As outlined above, Brazil has acted as a global role model for the fight against HIV/AIDS, with "perhaps the most successful experience yet realized in any developing country, but perhaps anywhere" (Parker 2003: 144). Furthermore, Brazilian as well as South African actors have consistently, through discursive interfaces, fought for lower prices of antiretroviral drugs. Even stronger in influencing GHG in this regard have been legal interfaces which often worked in conjunction with their discursive counterparts.

For a long time, pharmaceutical patents and the rights WTO member states posses vis-à-vis pharmaceutical MNCs under the TRIPS Agreement have been highly contentious issues. With its threat of compulsory licensing generic drugs, the Brazilian government has exerted pressure on pharmaceutical $\mathrm{MNCs}^{36}$ and has resisted pressure from governments of developed countries such as the United States. In the same vain, the court case, which the pharmaceutical industry filed against South Africa's 1997 Medicines and Related Substances Control Amendment Act exerted influence on GHG. It augmented the government's discursive case for lower prices of ARV treatment and - on a more general level - of fairness between the developing and developed countries under the TRIPS Agreement. On the topic of prices for ARVs there has thus been the biggest coherence between Brazil and South Africa. By using discursive and legal interfaces both governments have pursued confrontational strategies against MNCs in order to influence GHG.

On the whole, besides using legal and discursive interfaces in the quest for affordable ARVs, Brazil and South Africa have entered into contrasting relationships to GHG. Due to the comparably high degree of autonomy of both Brazil and South Africa, the fundamental determinants for conflict and cooperation with GHG can predominately be found in the realms of the state. Central actors such as the South African government can cause a conflictive relationship

\footnotetext{
${ }^{36}$ The threat gained credibility from the fact that Brazil as a middle-income country has had the laboratory facilities and the industrial capacities to produce generic drugs. The same holds true for South Africa.
} 
to GHG and can limit its influence. In Brazil, this dominating actor with a negative predisposition towards HIV/AIDS treatment and national-global interaction in this area has been absent. 


\section{Bibliography}

African National Congress (ANC) (2002) Let's tell the truth about South Africa, ANC Today, $2(9)$.

Ashraf, Haroon (2001) USA and Brazil end dispute over essential drugs. Lancet, 357: 2112.

Baer, Werner \& Cláudio Paiva (1996) Brasiliens inflationäre Erblast und der Plano Real. In: Calcagnotto, Gilberto \& Barbara Fritz (eds.): Inflation und Stabilisierung in Brasilien. Probleme einer Gesellschaft im Wandel. Schriftenreihe des Instituts für Iberoamerika-Kunde, Hamburg, Band 43: 66-93.

Bartsch, Sonja \& Lars Kohlmorgen (2005) Global Health Governance: Konflikt und Kooperation zwischen Nord und Süd in Neuen Institutionellen Strukturen, Paper presented at the workshop "Nord und Süd im Globalen Regieren Politikfelder, Akteure, Forschungsperspectiven”, German Institute for Development Policy, Bonn, 23/24 June, 2005.

BBC Brazil (2006) Empresas no Brasil são as que mais temem efeitos da AIDS. Jan., 12. Online available at: <www.bbc.co.uk/portuguese/reporterbbc/story/2006/01/060112_empresasaids brasilmb.shtml>.

Berkman, Alan et al. (2005) A Critical Analysis of the Brazilian Response to HIV/AIDS: Lessons Learned for Controlling and Mitigating the Epidemic in Developing Countries. American Journal of Public Health, 95 (7): 1162-1172.

Butler, Anthony (2005) South Africa's HIV/AIDS Policy, 1994-2004: How Can it be Explained?, African Affairs, 104 (416): 1-25.

Calcagnotto, Gilberto (1985) Brasiliens Antworten auf die Krise (1982-1985), Lateinamerika. Analysen, Daten, Dokumentation, 4: 63-74.

Cassier, Maurice \& Marilena Correa (2003): Patents, Innovation and Public Health: Brazilian Public-Sector Laboratories's Experience in Copying AIDS Drugs. Online available at: http://www.iaen.org/files.cgi/11069_part_1_n3_Cassier.pdf.

Castro, Mary Garcia \& Lorena Bernadete da Silva (2005) Responses to AIDS Challenges in Brazil: Limits and Possibilities. UNESCO/Ministério da Saúde, Brasília.

Central Bank of Brazil (1983) Annual report 1982, Brasília: Central Bank of Brazil.

Cepaluni, Gabriel (2005) Regimes Internacionais e o Contencioso das Patentes para Medicamentos: Estratégias para Países em Desenvolvimento, Contexto Internacional, 27(1): 51-99.

CNAIDS (2004) Protocol, June, 20, 71 ${ }^{\text {st }}$ Session. Brasília: Comissão Nacional de AIDS (CNAIDS). Online available at: <www.aids.gov.br/final/parcerias/atas.asp>.

Cohen, Jillian Clare \& Kristina Lybecker (2005) AIDS Policy and Pharmaceutical Patents: Brazil's Strategy to Safeguard Public Health. World Economy, 28 (2): 211-230. 
Connely, Patrick \& Sidney Rosen (2005) Provision of antiretroviral therapy by the private sector, Lancet, 365: 1925.

Department of Health (2000) HIV/AIDS/STD Strategic Plan for South Africa 2000-2005. Online available at: <http://www.doh.gov.za/docs/policy/aids-plan00-05.pdf $>$.

Doherty, Tanya \& Mark Colvin (2004) HIV/AIDS, in: Ijumba, Petrida \& Candy Day \& Antoinette Ntuli (eds.) South African Health Review 2003/2004, Durban: Health System Trust, p. 191-211. Online available at: <www.hst.org.za/uploads/files/SAHR2003 04 1.pdf >

Dickinson, David (2004) Corporate South Africa's response to HIV/AIDS: Why so slow?, Journal of Southern African Studies, 30 (3): 627-649.

Elmendorf, Edward \& Wendy Roseberry (1993) Structural adjustment: what effect on health? On vulnerability to HIV infection. International AIDS Conference 1993 June 6-11: 91-123.

Fontes, Miguel B. (1999) Interfaces entre as políticas internacionais e nacionais de AIDS. In: Parker et al.: Saúde, Desenvolvimento e Política. Respostas frente à AIDS no Brasil. Rio de Janeiro: ABIA Editora 34: 91-122.

Fritz, Barbara (2002) Entwicklung durch wechselkurs-basierte Stabilisierung? Der Fall Brasilien, Studien zur monetären Ökonomie, 28 Marburg: Metropolis.

Galvão, Jane (2000) AIDS no Brasil. A agenda de construção de uma epidemia. Rio de Janeiro: ABIA Editora 34.

Galvão, Jane (2002) A política brasileira de distribuição e produção de medicamentos antiretrovirais: privilégio ou direito? Cadernos Saúde Pública, 18 (1): 212-219.

Gauri, Varun \& Evan S. Lieberman (2004) AIDS and the State: The Politics of Government Responses to the Epidemic in Brazil and South Africa. Online available at: $<$ http://comparativepolitics.stanford.edu/Papers200405/Liebermanv2.440dJan17.pdf $>$.

Giovanella, Ligia \& Marcelo Firpo de Souza Porto (2004) Gesundheitswesen und Gesundheitspolitik in Brasilien, Arbeitpapiere 25/2004, Institut für Medizinische Soziologie des Klinikums der Johann Goethe Universität (ed.). Online available at: <http://www.links-netz.de/K texte/K giovanella brasilien.html>.

Gould, Jeremy (2005) Global Governance or Local Accountability? Reflections on the Politics of Public Policy in Poor Indebted Countries. Paper presented at the $11^{\text {th }}$ European Association of Development Research (EADI) Conference. Bonn, 23 September, 2005.

Government Communication and Information Service (GCIS) (2003) Statement on Special Cabinet Meeting: Enhanced Programme Against HIV and AIDS, Pretoria: 08.08.2003. Online available at: <http://www.info.gov.za>.

Gumede, William Mervin (2005) Thabo Mbeki and the Battle for the Soul of the ANC, Cape Town: Zebra Press. 
Hein, Wolfgang; Sonja Bartsch \& Lars Kohlmorgen (2006) Interfaces between Global and National Politics in GHG. Paper prepared for the International Workshop "Defining and Shaping the Architecture for Global Health Governance. Current Issues and Future Perspectives”, February, 22-24 2006, Hamburg: German Institute of Global and Area Studies (GIGA).

Hein, Wolfgang \& Lars Kohlmorgen (2003) (eds.), Globalisation, Global Health Governance and National Health Politics in Developing Countries. An Exploration into the Dynamics of Interfaces. Schriften des Deutschen Übersee-Instituts No. 60, Hamburg: German Overseas Institute.

Ijumba, Petrida et al. (2004) Access to antiretroviral therapy, in: Ijumba, Petrida \& Candy Day \& Antoinette Ntuli (eds.) South African Health Review 2003/2004, Durban: Health System Trust: 319-338. Online available at: <www.hst.org.za/uploads/files/SAHR2003 04 1.pdf > .

ISHR (2001) 54th World Health Assembly (Geneva, 14 to 22 May 2001), Geneva: International Service on Human Rights (ISHR), World Health Organization (WHO). Online available at: http://www.ishr.ch/About\%20UN/Reports\%20and\%20Analysis/WHO/WHO54thWHA.htm.

Kühl, Henrik (2002) TRIPS and AIDS in South Africa: New Actors in International relations - Weighing Patents, Pills and Patients, Los Angeles: Occidental College.

Lanoszka, Anna (2003) The global politics of intellectual property rights and pharmaceutical drug policies in developing countries, International Political Science Review, 24 (2): 181-197.

Lima, Nísia Trindade (2002) O Brasil e a Organização Pan-Americana da Saúde: Uma História em Três Dimensões. In: Finkelman, Jacobo (ed.) Caminhos da Saúde Pública no Brasil. Rio de Janeiro: Fiocruz: 23-116.

Lurie, Peter et al. (1995) Socioeconomic obstacles to HIV prevention and treatment in developing countries; the roles of the International Monetary Fund and the World Bank, AIDS 9: 539-546.

Mail \& Guardian (2003) Social Movements: "Ultra-Left" or "Global Citizens"?, Mail \& Guardian, 04.02.2003. Online available at: <www.mg.co.za $>$.

Mail \& Guardian (2005a) Official nod for voodoo trials?, Mail \& Guardian, 28.10.2005. Online available at: <www.mg.co.za $>$.

Mail \& Guardian (2005b) Is loveLife making them love life?, Mail \& Guardian, 19.08.2005. Online available at: <www.mg.co.za $>$.

Marais, Hein (2000) To the Edge: AIDS Review 2000, Pretoria: Centre for the Study of AIDS, University of Pretoria.

Marques, Marília Bernardes (2002) Acessibilidade aos medicamentos. O desafio de vincular ciência, tecnologia, inovação e saúde no Brasil. Brasília: Centro de Gestão e Estudos Estratégicos. 
Mbali, Mandisa (2005) The Treatment Action Campaign's Strategies to Government AIDS Policy in South Africa, Research Paper commissioned by the Global Health Governance Project of the German Overseas Institute. Online available at: http://www.duei.de/ghg/pdf/ProjectMbali4.pdf.

Médecins Sans Frontières (2003) Providing HIV Services Including Antiretroviral Therapy at Primary Health Care Clinics in Resource-Poor Settings: The Experience from Khayelitsha, Activity Report. Online available at: $<$ http://www.hst.org.za/uploads/files/khayelitsha03.pdf>.

Medici, André (1994) Impactos Socioeconômicos da AIDS. In: Parker, Richard et al. (1994) A AIDS no Brasil. Rio de Janeiro: Relume: 325-329.

Mercadante, Otávio Azevedo (2002) Evolução das Políticas e do Sistema de Saúde no Brasil. In: Finkelman, Jacobo (ed.): Caminhos da Saúde Pública no Brasil. Rio de Janeiro: Fiocruz: 235-313.

Oliveira, Maria Auxiliadora \& Ângela Esher, (2004): Acesso Universal ao Tratamento para as Pessoas Vivendo com HIV e AIDS no Brasil. In: Bermudez, Jorge et al.: Acceso a Medicamentos: Derecho Fundamental, Papel del Estado. Rio de Janeiro: Escola Nacional de Saúde Pública: 233-250

PAHO (2005) Brasil - O Perfil do Sistema de Serviços de Saúde. Brasília: Pan American Health Organisation (PAHO), March, 1-38. Online available at: www.lachsr.org/documents/ healthsystemprofileofbrazil-EN.pdf.

Parker, Richard et al. (2001) As estratégias do Banco Mundial e a resposta à AIDS no Brasil. In: Barros, Flávia (ed.) As estratégias dos bancos multilaterais para o Brasil (2000-2003). Brasília: Rede Brasil sobre Instituições Financeiras Multilaterais. Bra: 107-130.

Parker, Richard (2003) Building the foundations for the response to HIV/AIDS in Brazil: the development of HIV/AIDS policy, 1982-1996, Divulgação em Saúde para Debate (27): 143-183.

Pawinski, Robert \& Umesh Lalloo (2002) Throwing a lifeboat to the Titanic: the Global Fund and HIV in South Africa and KwaZulu-Natal, Aids Analysis Africa, 2002. Online available at: $<$ http://www.redribbon.co.za/learn/user_page.asp?page_number=2985\&prev_p age $=2938>$.

Piola, Sérgio F. \& J. G. Biasoto (2001) Financiamento do SUS nos anos 90. In: Negri, Barjas \& G. de Giovanni (ed.) Brasil Radiografia da Saúde, Campinas: Unicamp: 219-232.

PMA (1998) Pharmaceutical Company Lawsuit (forty-two applicants) against the Government of South Africa (ten respondents). Pharmaceutical Manufacturers Association (PMA). Access: 07.02.2006. Online available at: http://www.cptech.org/ip/health/sa/pharmasuit.html.

Putzel, James (2004) The global fight against AIDS: How adequate are the national commissions?, Journal of International Development, 16: 1129-1140. 
Sangmeister, Hartmut (1992) Brasilien. In: Nohlen, Dieter \& Franz Nuscheler (eds.) Handbuch der Dritten Welt. Südamerika, 3rd. ed., Bonn: J.H.W. Dietz Nachf.: 219276.

Schneider, Helen \& Lucy Gilson (1999) Small fish in a big pond? External aid and the health sector in South Africa, Health Policy and Planning, 14 (3): 264-272.

Schneider, Helen (2001) A struggle for symbolic power, Siyaya Magazine, 8 (Winter): 18-21.

Senado Federal (2003) Constituição da República Federativa do Brasil. Brasília: Subsecretaria de Edições Técnicas.

Silva, Alex Giacomelli da (2005) Poder Inteligente - A questão do HIV/AIDS na Política Externa Brasileira, Contexto Internacional, 27 (1): 127-158.

Stevens, Marion (ed.) (2004) Responses of two Large South Africa Companies to HIV/AIDS in the Workplace, Studies funded by the European Union. Johannesburg: Centre for Health Policy, University of the Witwatersrand.

Strode, Ann \& Kitty Barrett Grant (2004) Understanding the Institutional Dynamics of South Africa's Response to the HIV/AIDS Pandemic, Pretoria: Institute for Democracy in South Africa (IDASA).

Sunday Independent (2005) Manto's Aids Comments spark Outrage, Sunday Independent, 08.05.2005. Online available at: <www.sundayindependent.co.za $>$.

Sunday Times (1999) Ray of light for HIV babies, Sunday Times, 10.01.1999. Online available at: <www.sundaytimes.co.za $>$.

Sunday Times (2000) It's so easy to save our AIDS babies, Sunday Times, 01.10.2000. Online available at: $<$ www.sundaytimes.co.za $>$.

Tachinardi, Maria Helena (1993) A Guerra das Patentes: O Conflito Brasil X EUA sobre Propriedade Intelectual. Rio de Janeiro: Paz e Terra.

Teixeira, Paulo (1997) Políticas Públicas em AIDS. In: Políticas, Instituições e AIDS. Enfrentando a Epidemia no Brasil. Rio de Janeiro: ABIA/Zahar: 43-68.

Terto Jr., Veriano (1997) A AIDS e o local de trabalho no Brasil. In: Parker, Richard (ed.): Políticas, Instituições e AIDS. Enfrentando a epidemia no Brasil. Rio de Janeiro: ABIA/Zahar: 135-175.

Tesouro Nacional (2006) Renegotiated Debt (BIB, IDU and Bradies). Online available at: $<$ www.tesouro.fazenda.gov.br/english/public_debt/downloads/Renegotiated_D ebt_IDU_BIB.pdf>.

Treatment Action Campaign (TAC) (2003) Treatment Action Campaign (TAC) Report for January 2002 - February 2003. Online available at: <http://www.tac.org.za $>$.

Treatment Action Campaign (2005) Treatment Action Campaign: Annual Report, 1 March 2004-28 February 2005, Online available at: <www.tac.org.za>. 
UNAIDS (2001): Integrated Plano of the UNAIDS Theme Group to support the National Response on STD/HIV/AIDS. Brazil. Brasília: Joint United Nations Programme on HIV/AIDS (UNAIDS) Brazil. Online available at: http://www.br.undp.org/hiv/UNAIDS\%20Brazil\%20Integrated\%20Plan.pdf.

UNAIDS (2004) 2004 Report on the Global AIDS Epidemic: $4^{\text {th }}$ Global Report, Geneva: Joint United Nations Programme on HIV/AIDS (UNAIDS).

UNAIDS/WHO (2005) AIDS Epidemic Update. December 2005, Geneva: Joint United Nations Programme on HIV/AIDS (UNAIDS)/World Health Organization (WHO).

UNDP (2005) Human Development Report 2005. International Cooperation at a Crossroads. Aid, Trade and Security in an Unequal World. New York: United Nations Development Programme (UNDP).

United States (2006) Frequently Asked Questions PEPFAR. Web page United Sates Embassy South Africa. Pretoria: United States Embassy South Africa. Access: 07.02.2006. Online available at: $<$ http://usembassy.state.gov/posts/sf2/wwwhquestions.html>.

United States Global AIDS Coordinator (2005) Engendering bold Leadership: The President's Emergency Plan for AIDS Relief. First Annual Report to Congress. Washington, DC: United States Global AIDS Coordinator.

Vásquez, Ian (1996) The Brady Plan and Market-Based Solutions to Debt Crises. In: The Cato Journal, $16 \quad$ (2): 1-7. Online available at: $<$ www.cat.org/pubs/journal/cj16n2-4.html $>$.

Weinel, Martin (2005) AIDS Policy in South Africa: Between Denial and Action, Working Paper, Hamburg: German Overseas Institute.

Weissman, Robert (2001) AIDS and developing countries: facilitating access to essential medicines, Foreign Policy in Focus, 6 (6) March 2001.

Willan, Samantha (2004) Briefing: recent changes in the South African government's HIV/AIDS policy and its implementation, African Affairs, 103: 109-117.

Wogart, Jan Peter \& Gilberto Calcagnotto (2006) Brazil's Fight against AIDS and its Implications for Global Health Governance. In: Healthcare Quarterly, 9 (1): 90-103.

World Bank (1997) Health, Nutrition and Population (Sector Strategy). Washington: World Bank.

World Bank (1998) World Development Indicators 1998. Washington, DC: World Bank.

World Bank (1999) Intensifying Action Against HIV/AIDS in Africa: Responding to a Development Crisis, June, Washington, DC: World Bank.

World Bank (2004) Project Performance Assessment Report Brazil. First and Second AIDS and STD Control Projects (Loans 3659-BR and 4392-BR). Report No. 28819. Washington, DC: World Bank. 
World Bank (2005a) World Development Report 2006. Equity and Development. Washington, DC: World Bank/Oxford University Press.

World Bank (2005b) Evaluation of the World Bank's Assistance in Responding to the AIDS Epidemic: Brazil Case Study, Washington, DC: World Bank Operations Evaluation Department (OED), World Bank.

\section{Interviews Cited}

Bonifácio, Raldo, Assistant Coordinator, Brazilian Sexually Transmitted Diseases/AIDS Programme (BSAP), Brasília, 14.9.2004.

Herlt, Claudia, Health Project Coordinator, German Technical Cooperation Agency GTZ, Brasília, 13.9.2004.

Milhomem, Luciano, Media and Partnerships Consultant, UNAIDS-Brazil, Brasília, 15.9.2004.

O’Connor, John, Managing Director, LoveLife, Johannesburg, 11.05. 2005.

Ramlagan, Shandir, Researcher, Human Sciences Research Council (HSRC), Cape Town, 11.05.2005.

Teixeira, Paulo R., former Director, Brazilian Sexually Transmitted Diseases/AIDS Programme (BSAP)/currently Director, AIDS Reference and Training Center CRT São Paulo, São Paulo, 24.8.2004. 